\title{
AGE MANAGEMENT AND ITS ARCHITECTURE IN POLISH TRADITIONAL VERSUS KNOWLEDGE-BASED COMPANIES
}

This article concerns the management of mature employees and is based on representative research of Polish employers ( $\mathrm{N}=928)$. At the beginning, age management is defined in the context of the emerging challenges faced by today's organisations. One of the most important challenges for management is ageing and the development of an appropriate policy which would counter the negative consequences of managing age and make use of the positive attributes of elderly employees - implemented as a coherent age management concept. The aim of this article is to present the differences and similarities in age management between Polish traditional and knowledge-based organisations. Thus, three dimensions of age management are presented: institutional, instrumental, and functional. The results of this study have been compared to other studies, thus shedding additional light on age management in Poland. Traditional and knowledge-based organisations obviously differ, and in our research, the biggest differences were found in their perception of elderly people and in the instrumental dimension of age management architecture. It can be expected that the development and growing popularity of age management will increasingly erase the remaining differences. It is probable that the differences in the institutional and functional spheres will disappear altogether, while the instrumental sphere of age management will remain differentiated. This differentiation is not about the use of an age management instrument as such, but about its characteristics, related to the degree of formalism, the scope of content, and the number of users. Traditional and knowledge-based organisations can also differentiate their accents in different spheres related to human resources management. It seems likely that this will occur in the near future, alongside changes which will dynamically implement those practices aimed at bringing equal and synergistic benefits to both elderly workers and employers.

Keywords: age management, silver economy, knowledge-based organisations, traditional organisations, older employees, age

DOI: $10.15611 /$ aoe.2019.2.17

\section{INTRODUCTION}

In an organisational environment we can observe a number of changes associated with the increased importance of intangible assets, globalisation, internationalisation, tertiarisation, informatisation as well as the growth of

\footnotetext{
${ }^{*}$ Faculty of Economics and Sociology, University of Lodz.
} 
competition and innovation. The most significant among them include competitive, innovative and social challenges (Kaleta and Witek-Crabb, 2015).

Organisations also are particularly faced with the impacts of ageing. In Poland, the phenomenon of an ageing population affects employers. The consequences of this will encompass an even greater number of Polish companies in the future. Therefore the aim of this paper is to present the differences and similarities in age management architecture between Polish traditional and knowledge-based organisations. Given the importance and the widespread consequences of demographic change, it is surprising to see how little scientific research related to aging has been carried out so far in the field of business and management. Academics are slowly beginning to perceive this phenomenon as a challenge for the economy on a macro scale, and in particular for business entities (Kohlbacher and Herstatt, 2011). This publication is an attempt to partially fill this gap.

Age management is a relatively new issue in the scientific literature. The term "age management" may refer to various dimensions of human resources management (HRM) within an organisation which have a clear focus on ageing (Walker, 1997), but it can also refer to the overall policy or collective bargaining (Walker, 2005). Age management instruments combat age barriers and help create an environment in which individual employees are able to exploit their potential without being disadvantaged due to their age (Naegele and Walker, 2006). Broadly speaking, age management is the taking into account by HRM of a new variable - the ageing resources of the organisation, and the expressions "older", "mature", "45+", "50+" will be used interchangeably. This term will not be used interchangeably with multigenerational management, which has been reserved for generations.

Age management strategy as a personnel strategy is based on the overall business strategy (Zając, 2012). It seems important to answer the question of whether Polish knowledge-based and traditional organizations use a different architecture of age management.

\section{AGE MANAGEMENT - REVIEW OF THE LITERATURE}

Age management is a relatively new issue that appeared in foreign literature more than 20 years ago, and has been present in Polish literature for over a dozen years. At the same time, there is a limited interest of Polish academic centres in research in this field (Kołodziejczyk-Olczak, 2013). Previous research results confirm that age management as a planned and purposeful activity does not exist in Polish firms, only some symptoms of an 
increasing awareness of age management being a necessity can be observed. Firms do make some attempts to this end -30.7 percent of managers try to form age-diversified teams or transfer workers between jobs. When the survey results were analysed, some symptoms of concealed conflict between generations were also discovered (younger workers are critical of older workers). At the same time, elderly people are willing to share their knowledge, as indicated by as many as $92.9 \%$ of workers, and are more satisfied with work $-67.1 \%$; they are mostly women and people with tertiary education (Urbaniak, 2011).

Employers maintain that older people are not discriminated against almost 80 percent of employers that plan to recruit workers declare that candidates aged 50+ will also be considered. It is also optimistic that workers perceive that knowledge transfers do take place: 60 percent of workers aged $50+$ state that their firm/institution has mechanisms and a practice of the more experienced workers sharing their knowledge with younger co-workers; the most common form was daily, informal conversations and cooperation (Perek-Białas et al., 2011). The types of solutions that employers use nowadays include ergonomic adaptations $(35 \%)$, training for older workers $(33 \%)$, and flexible working hours $(29 \%)$. Around one-half of the surveyed firms had introduced at least two solutions and more than $40 \%$ of firms do not use any elements of age management strategy (Mazur et al., 2009).

Polish firms do not have an age management culture and do not take real actions directed towards older workers. A vicious circle thus appears: no actions are taken because of stereotypical, negative and cost-based perceptions of elderly workers, and a reluctance to employ and retain older people. At the same time, the low quality and inappropriate working conditions decrease older workers' motivation to work, to improve their qualifications, and to work longer (Perek-Białas and Turek, 2010). The same factors prevent the implementation of age management practices.

The most important stakeholders of age management are older persons. That is why it is extremely important how they are perceived. Researchers have noted that "employers frequently use stereotypes about persons aged $45+$. This is particularly noticeable if we compare the opinions of employers who have workers aged $45+$ and those who do not" (Wiktorowicz, 2010). At the same time many positive characteristics of this group are indicated: "Older people are appreciated above all for their knowledge, experience, loyalty, and the ability to predict the consequences of what they are doing. Less positive opinions are less frequent". The same applies to the self- 
assessments given by older people: "These respondents stress that they are open to learning new skills and the main problem is that employers fail to see that they can be trained" (Woszczyk, 2011).

However, coaches working with older people perceive barriers to educating them, describing them as "age-limited", "one's prominent position in the milieu", "30-40 in one workplace can be a considerable hindrance", "the person's self-image, the feeling of being old, that young people can do everything." (Urbaniak and Kołodziejczyk-Olczak, 2008). According to HR specialists, the situation of "people aged $50+$ in the labour market is very difficult, because of the characteristics of this age group, a stereotypical perception of people aged 50+, and cultural factors, which overall significantly discourage employers from employing older workers" (Woszczyk, 2011). The barriers are not directly related to open conflicts, but rather to generational isolation. The conflict of generations is set mainly in the psychological context. It is certainly a problem for a person aged $50+$ to accept the role of a student to a younger colleague, and at the same time, for a person below 35 years of age to be a teacher at that age (Misztal, 2006).

The review of foreign surveys shows that the attitude to the problem of aging and attitude and behaviour of employers towards aging employees and the extension of professional life is changing (Henkens et al., 2008). With reference to individual instruments of age management, research has touched on the need to reconcile personal and professional life, which is extremely important for human resources management and for social policy (Aassve et al., 2012); talent management in the context of the lack of available talents and not limiting the recruitment to recruit employees in the so-called prime of life (Naegele and Walker, 2006) and the need for intergenerational knowledge transfer and conflict avoidance in the workplace (Vendramin, 2008; Delay and Méda, 2008).

Supporting the ability to work in elderly employees and good age management practices are key concepts and tools of contemporary work life and conscious improvement (age-friendly) work environment (Clas-Hagan et al., 2011). Authors dealing with the idea of older people, include those who are frail and disabled, regardless of their chronological age and inter-generational solidarity and fairness between generations (Walker and Zaidi, 2016).

Implementation of the silver economy favours the elimination of age conflicts, consisting in the formation of the opposition: young against the older, the older against the young (Macnicol, 2006). The development of the silver economy is guaranteed by the size and specificity of demand in the "silver market", offering great opportunities for companies (Reinmoeller, 
2011) and respecting the law prohibiting discrimination on the basis of age. The climate of age discrimination negatively affects overall performance through affective engagement (Kunze et al., 2011).

\section{ARCHITECTURE OF AGE MANAGEMENT - METHODOLOGICAL ASPECTS}

Companies may use different configurations of age management architecture. Age management is part of a more broadly-defined organisational architecture (Nadler et al., 1992, pp. 4-14). This architecture may be understood comprehensively, together with the social sphere and the sphere of work. Architecture is an "applied art", consumed by "ordinary people". It sets the framework (Lepak and Snell, 1999, 2002) for organisational life rather than specifying what life should be like. In terms of HRM we can talk about HRM architecture understood as a configuration of HRM functions (a functional approach), HRM operators (institutional) and HRM tools (instrumental) which should be established to create value for customers, employees, shareholders, and society at large (Ludwiczyński, 2005, p. 3). This issue is important in the context of an organisation's policy of age management, which takes place on many HRM levels and integrates activities conducted on many levels of management within the organisation. Therefore, analyzing the institutional area includes the level of decision makers in terms of age management (owner, director, managerial or specialist level) and how decision-makers perceive elderly employees - in the context of their general characteristics, competences, approaches and opportunities, as well as an assessment of their chances in the labour market in the event of job loss. The indicated subject to observation in this part was also cooperation with one of the most important actors in the process of age management - trade unions.

Interpreting the functional sphere, one can review the personnel function from the employee's entry to the organization, to his/her exit. In the case of age management the author decided to include the following functions: recruitment, organization of work, remuneration, motivation, and intergenerational transfer of knowledge. For each function, specific indicators were selected, focusing on tools (instrumental approach) that fundamentally affect the retention of mature employees in employment and their recruitment from the labour market.

Considering the above, the level and extent of implementation of age management in Polish organisations, as well as the barriers, opportunities 
and conditions, have been evaluated. Representative surveys of Polish employers have shown many differences between traditional and knowledge-based organisations. To investigate age management strategies and practices used by Polish employers we used a database of 1011 employers ${ }^{1}$. The sampling frame was the Polish employer data base, HBI Polska. On the basis of one of the survey questions, organisations based on traditional knowledge were distinguished, and the further analysis was divided into two sub-groups: a) traditional organisations, i.e. entities which declared that their material resources (own buildings and land, machinery, etc.) are their primary assets; and b) knowledge-based organisations, i.e. the entities which declare that intangible resources (staff expertise, know-how, etc.) are their main assets. This approach reduced the sample size to 928 subjects, however the sample still meets the conditions of representativeness and thus the results can be generalised for the population of employers in Poland. The analysis of the results was performed using the chi-square test of independence or Fisher's exact test.

The study used CATI (Computer Assisted Telephone Interview) which is a quantitative research method based on the scheme of an individual questionnaire interview. In this study the questionnaire was directed to the managing director or owner who, in order to complete the questionnaire, based on the knowledge of age management in the organization and in accordance with the CATI methodology (the possibility of multiple return), could delegate a human resources manager or another manager.

\section{INSTITUTIONAL ASPECTS OF AGE MANAGEMENT - A SURVEY OF POLISH EMPLOYERS}

The starting point for the discussion is an analysis of employers' perceptions of older employees in terms of their physical fitness and ability to do heavier work or jobs which require better physical condition. At the same time, such employees are likely to be less motivated to learn or to develop as a person and an employee, and occupational burn-out syndrome may appear more frequently.

\footnotetext{
${ }^{1}$ A database of 1011 employers from the Equal opportunities in the labour market for people aged 50+. This was a systemic project implemented by the Human Resources Development Centre in partnership with the University of Łódź, for the Ministry of Labour and Social Policy. The project is co-financed by the European Social Fund under the Human Capital Operational Programme, and the author served as manager for the coordination of activities at the University of Łódź.
} 
It is thus necessary to discern the opinion of the managerial staff and/or company owners in charge of shaping the company's age management policy. This is related to the institutional, subjective dimension of age management. Therefore, the characteristics of the respondents who answered all the questions in the questionnaire form its explicit section, declaring their strongest involvement in this area of management. The positioning of people in charge of age management in the organisation's structure may also be an indication of how the process is perceived and how much weight is attached to it (Table 1).

Table 1

Respondents' posts in the employer survey $(\%, \mathrm{~N}=928)$

\begin{tabular}{l|c|c}
\hline \multicolumn{1}{c|}{$\begin{array}{c}\text { Respondents by their posts } \\
(\mathbf{p}=\mathbf{0 . 1 5 4})\end{array}$} & Traditional & Knowledge-based \\
\hline Owner & 65.1 & 69.0 \\
\hline Director or president / chairman & 15.3 & 10.2 \\
\hline HRM deputy director / manager & 14.6 & 16.5 \\
\hline Other managerial post & 5.0 & 4.3 \\
\hline Total & 100 & 100 \\
\hline
\end{tabular}

* statistically significant.

Source: author's own elaboration.

The conclusion can be drawn that in 80 out of 100 Polish organisations, age management decisions are made by their owners or at the top executive level, which does not differentiate Polish employers statistically significantly (Table 1). The related lack of freedom to frame the process at the strategic level together with the scarcity of age management activities imply that those who make decisions are not as yet fully aware of what demographic changes are taking place in their environment, nor what changes are predicted to take place in the future.

Moreover, it is not possible to explain the relatively limited interest in this phenomenon in terms of the decision-makers' short time of service and/or insufficient knowledge of the needs and potential of the company, as they have sufficiently long experience to analyse the needs properly. The average number of years worked by respondents in traditional organisations was 28.8 years, and only slightly less in the knowledge-based organisations 27.2. Periods of work as managers in organisations were also quite long, respectively 13.5 and 12.3 years. Company owners, directors or presidents, therefore, had enough time to learn about the specific character of their 
organisations and the expectations and capabilities of workers, including those of an older age. That being the case, their opinions are interesting.

The natural decrease in physical fitness (Table 2) is perceived significantly less often by knowledge-based organisations $(42.7 \%$ versus $52.4 \%$ ). Decreased fitness may limit the possibilities of transferring an employee to other jobs; a solution not considered more frequently by traditional firms $(63.8 \%$ versus $49.8 \%)$.

Table 2

Employers' views of older workers with respect to their cooperation and employment in traditional and knowledge-based organisations $(\%, \mathrm{~N}=928)$

\begin{tabular}{|c|c|c|c|}
\hline $\begin{array}{l}\text { How frequently have the following } \\
\text { situations occurred? }\end{array}$ & Type of organisation & No & Yes \\
\hline \multicolumn{4}{|c|}{ Statistically differentiating factors } \\
\hline \multirow{2}{*}{$\begin{array}{l}\text { Younger workers reluctant to cooperate with } \\
\text { older ones }(\mathrm{p}=0.004)^{*}\end{array}$} & Knowledge-based & 84.7 & 15.3 \\
\hline & Traditional & 78.5 & 21.5 \\
\hline \multirow{2}{*}{$\begin{array}{l}\text { Natural decrease in physical fitness in jobs } \\
\text { that require it }(\mathrm{p}=0.007)^{*}\end{array}$} & Knowledge-based & 77.8 & 22.2 \\
\hline & Traditional & 80.5 & 19.5 \\
\hline \multirow{2}{*}{$\begin{array}{l}\text { Workers aged } 45+\text { reluctant to do training } \\
(\mathrm{p}<0.001)^{*}\end{array}$} & Knowledge-based & 85.18 & 14.9 \\
\hline & Traditional & 77.8 & 22.2 \\
\hline \multirow{2}{*}{ Job burnout $(\mathrm{p}=0.018)^{*}$} & Knowledge-based & 81.3 & 18.7 \\
\hline & Traditional & 82.7 & 17.3 \\
\hline \multirow{2}{*}{$\begin{array}{l}\text { Fewer possibilities of transferring workers to } \\
\text { other jobs }(\mathrm{p}=0.001)^{*}\end{array}$} & Knowledge-based & 82.1 & 17.9 \\
\hline & Traditional & 84.6 & 15.4 \\
\hline \multirow{2}{*}{$\begin{array}{l}\text { Fewer possibilities to introduce another form } \\
\text { of work organisation to make heavy tasks } \\
\text { easier through the assistance of a younger } \\
\text { person }(p<0.001)^{*}\end{array}$} & Knowledge-based & 80.8 & 19.2 \\
\hline & Traditional & 86.6 & 13.4 \\
\hline \multicolumn{4}{|c|}{ Non-statistically differentiating factors } \\
\hline \multirow{2}{*}{$\begin{array}{l}\text { No focus on competition, so their } \\
\text { performance was inferior to their younger } \\
\text { colleagues }(p=0.078)\end{array}$} & Knowledge-based & 85.8 & 14.2 \\
\hline & Traditional & 84.3 & 15.7 \\
\hline \multirow{2}{*}{$\begin{array}{l}\text { People aged } 45+\text { not having the required } \\
\text { skills }(p=0.226)\end{array}$} & Knowledge-based & 86.8 & 13.2 \\
\hline & Traditional & 88.9 & 11.1 \\
\hline \multirow{2}{*}{$\begin{array}{l}\text { Mismatch with the company's organisational } \\
\text { culture }(\mathrm{p}=0.078)\end{array}$} & Knowledge-based & 91.0 & 9.0 \\
\hline & Traditional & 89.2 & 10.8 \\
\hline \multirow{2}{*}{$\begin{array}{l}\text { The marketing image of the company likely } \\
\text { to look "old", lacking in dynamism and } \\
\text { modernity }(\mathrm{p}=0.054)\end{array}$} & Knowledge-based & 87.5 & 12.5 \\
\hline & Traditional & 86.6 & 13.4 \\
\hline
\end{tabular}

* statistically significant

Source: author's own elaboration. 
The limited options to introduce other forms of work organisation to make heavier work less onerous via the assistance of a younger person are perceived significantly less often by organisations where intangible assets are the most important $(80.8 \%$ versus $86.6 \%$ of responses "never", "very rarely" and "rarely").

Table 3

The employment situation of older workers and the type of organisation

\begin{tabular}{c|c}
\hline Traditional organisations & Knowledge-based organisations \\
\hline Reluctant to undertake training* & Decreased physical fitness* \\
\hline $\begin{array}{c}\text { Younger people are reluctant to } \\
\text { cooperate* }\end{array}$ & $\begin{array}{c}\text { No possibilities of transferring them to other } \\
\text { jobs* }\end{array}$ \\
\hline They are not competition-minded & $\begin{array}{c}\text { Limited opportunities to implement other } \\
\text { forms of work organisation* }\end{array}$ \\
\hline Marketing culture & Lack of skills \\
\hline Mismatch with organisational culture & Job burnout \\
\hline * See Table 1.
\end{tabular}

Source: author's own elaboration.

Knowledge-based organisations clearly perceive the "physical" deficiencies of elderly employees - this opinion is expressed by almost one in four employers in Poland. This may be due to the adopted human resources strategy and the lack of perception of possible problems in employee development and training. This view also seems to be less stereotypical.

Traditional organisations significantly more frequently observe employees' reluctance to undertake training (almost one in four firms), and a worrying finding may be that this observation is generally made by organisations that are more willing to use this approach to develop their personnel, including using training co-funded from EU projects. The traditional organisations also more frequently perceive resistance to cooperation between younger and older workers, an indication of actual or perceived rivalry.

An important element of employers' perceptions is their opinion on what the labour market situation of their workers might be. The respondents were asked to assess the possibility of workers finding a new job if they lost the one they had. The results were rather unfavourable for older workers (Table 4). Unfortunately, according to the majority of answers, elderly people would definitely not find a job similar to what they had (29.2\% of traditional organisations and $27.6 \%$ of knowledge-based organisations). The possibility 
of a new job being found was evaluated more positively by employers who predominantly used intangible assets $(24.9 \%$ versus $19.2 \%$ of traditional organisations; the difference is not statistically significant).

Table 4

Opinions on older people's chances of finding a new job if dismissed by their current employer $(\%, \mathrm{~N}=928)$

\begin{tabular}{l|c|c}
\hline \multirow{2}{*}{$\begin{array}{c}\text { Would it be possible for people aged 45+ } \\
\text { to find a similar job in the local labour market? }\end{array}$} & \multicolumn{2}{c}{$\begin{array}{c}\text { Key resources } \\
\text { in the organisation }\end{array}$} \\
\cline { 2 - 3 } & Traditional & Intangible \\
\hline Definitely yes $(\mathrm{p}=0.062)$ & 19.2 & 24.9 \\
\hline It depends on how resourceful the worker is $(\mathrm{p}=0.001)^{*}$ & 11.2 & 20.4 \\
\hline It depends on the worker's competencies $(\mathrm{p}=0.576)$ & 23.5 & 25.2 \\
\hline It depends on what job they have done so far $(\mathrm{p}=0.439)$ & 26.2 & 23.7 \\
\hline Definitely not $(\mathrm{p}=0.626)$ & 29.2 & 27.6 \\
\hline I don't know $(\mathrm{p}=0.111)$ & 4.6 & 7.5 \\
\hline
\end{tabular}

* See Table 1.

Source: author's own elaboration.

However, the perception of a link between the labour market situation of a worker and his or her initiative is a factor that differentiates employers in Poland statistically significantly, as the link is indicated by 11.2 percent of traditional organisations compared with 20.4 percent of knowledge-based organisations (i.e. almost twice as many).

The awareness of the multitude of situations related to the employment of elderly workers, their state of health, attitudes, handling a job-seeking situation, or different worker preferences is actually declarative. A behavioural, visible fact, however, is the actual number of older workers who are employed, which varies significantly among organisations depending on the predominant type of resources they use. Older workers are more frequent in traditional organisations (75.4 percent compared with 66.1percent of knowledge-based organisations).

It would, therefore, be interesting to learn why older workers are employed, given the rather critical opinions mentioned above. It may be that traditional organisations are unable to get the workers they need with sufficiently high skills because of the financial conditions they offer or other aspects of management that the potential candidates disapprove of, such as promotion opportunities within the organisation, the availability of training, 
management style, and the organisational culture or climate. The creation of an inappropriate image of the employer, including employer branding, may also be a problem. Traditional organisations may also lean towards a stereotypical approach and evaluate older workers as having a lower value.

Trade unions are an important partner to the participatory process in organisations. Because their mission is to defend and protect workers' interests, they naturally have an interest in older workers too. However, analysis of answers to the question about why employers cooperate with trade unions on issues relating to older workers reveals that such cooperation is practically non-existent (Table 5).

Table 5

Cooperation with trade unions $(\%, \mathrm{~N}=928)$

\begin{tabular}{l|c|c}
\hline \multicolumn{1}{c}{$\begin{array}{c}\text { Did you cooperate with on-site trade unions } \\
\text { on the work, recruitment or dismissals } \\
\text { of people aged 45+? }(\mathbf{p}=\mathbf{0 . 0 3 1})^{*}\end{array}$} & \multicolumn{2}{|c}{ Key organisational resources } \\
\cline { 2 - 3 } & Traditional & Intangible \\
\hline No, we don't have trade unions & 86.2 & 96.4 \\
\hline No, for the lack of initiative from the trade unions & 0.4 & 1.1 \\
\hline Yes, there was cooperation with the trade unions & 0.8 & 0.6 \\
\hline We neither recruited nor dismissed workers aged 45+ & 12.6 & 6.9 \\
\hline
\end{tabular}

* See Table 1.

Source: author's own elaboration.

In knowledge-based organisations, cooperation with trade unions was initiated significantly less frequently because of the almost complete absence of trade unions (workers do not have this type of representation in 96.4 percent of these organisations). Generally, the reason for the marginal cooperation with unions was the low degree of unionisation of the organisations surveyed. Cooperation is undertaken in relation to consultations on redundancies, then HRM matters, and sporadically on subjects related to welfare and management in general.

By collecting data from institutional age management research, it can be seen that both the cooperation with trade unions and the opinions about elderly workers by those responsible for shaping and implementing age management policies are different in traditional and knowledge-based organisations. 


\section{FUNCTIONAL AND INSTRUMENTAL AGE MANAGEMENT TOOLS USED BY POLISH EMPLOYERS}

The way employers perceive their older workers largely determines the type of age management strategy implemented. Organisational strategy and the company's culture and structure influence the functions and tools adopted to manage this resource. The employers' approach to age management can be measured taking into account the type of instruments applied to this end. An inventory of age management tools has provided information about the strategies followed by Polish enterprises, divided into traditional and knowledge-based organisations (Table 6). Whether the strategies were deliberate or spontaneous is difficult to establish.

The proportion of traditional organisations with recruitment plans that allow for workers' age is statistically significantly greater in traditional than in knowledge-based organisations $(18.8 \%$ versus $10.8 \%)$. The situation is similar regarding the age-oriented organisation of work $(18.8 \%$ versus $13.4 \%$ ). Forms of employment were also matched more frequently by traditional than knowledge-based employers, but the difference was not statistically significant $(19.2 \%$, versus $15.9 \%)$. For knowledge-based organisations, which perceive their intangible resources as their main advantage, age management philosophy and the successful implementation of tools for promoting it are very important.

In fact, modern organisations more frequently remunerate for competencies and for workers' performance, and assign tasks based on psychophysical capabilities. These methods of establishing remuneration follow the tendency to individualise workers' remuneration and to manage competencies, which is characteristic for the pro-efficiency approach. Within the instrumental approach, two types of organisations can be identified. Modern employers use the following instruments significantly more frequently than traditional employers do:

- related to knowledge management: such as career guidance and the transfer of knowledge, coaching, mentoring, age-diversified teams, and knowledge management;

- related to building involvement: rewarding for individual performance, for competencies, selection of workers based on their psychophysical capabilities.

Compared with knowledge-based organisations, traditional organisations more frequently use seniority-based promotions and offer allowances for years of service, pointing to a somewhat petrified approach to motivation 
Table 6

Age management functions and tools used by employers (answers YES, \%, N=928)

\begin{tabular}{|c|c|c|c|}
\hline \multicolumn{2}{|r|}{ Specification } & \multirow{2}{*}{$\begin{array}{c}\text { Traditional } \\
\text { organisations }\end{array}$} & \multirow{2}{*}{$\begin{array}{c}\text { Knowledge- } \\
\text { based } \\
\text { organisations }\end{array}$} \\
\hline Functions & Tools & & \\
\hline \multirow[t]{2}{*}{$\begin{array}{l}\text { Recruitment of } \\
\text { employees }\end{array}$} & $\begin{array}{l}\text { Recruitment planning allowing for workers' } \\
\text { age }(p=0.001)^{*}\end{array}$ & 18.8 & 10.8 \\
\hline & $\begin{array}{l}\text { Forms of employment selected to match } \\
\text { workers' age }(p=0.235)\end{array}$ & 19.2 & 15.9 \\
\hline \multirow[t]{3}{*}{$\begin{array}{l}\text { Organization of } \\
\text { work }\end{array}$} & $\begin{array}{l}\text { Working time organised allowing for } \\
\text { workers' age }(p=0.035)\end{array}$ & 18.8 & 13.4 \\
\hline & $\begin{array}{l}\text { Tasks assigned allowing for workers' } \\
\text { psychophysical characteristics }(\mathrm{p}=0.042)^{*}\end{array}$ & 58.5 & 65.6 \\
\hline & $\begin{array}{l}\text { Health }- \text { related services (e.g. free bonus } \\
\text { related to improving the health of employees) }\end{array}$ & 12,7 & 13,00 \\
\hline \multirow[t]{3}{*}{ Remuneration } & $\begin{array}{l}\text { Rewarding for individual achievements } \\
(\mathrm{p}=0.013)\end{array}$ & 66.5 & 74.6 \\
\hline & Rewarding for competencies $(\mathrm{p}=0.009)^{*}$ & 66.3 & 74.8 \\
\hline & Allowances for years of service $(\mathrm{p}=0.740)$ & 27.3 & 26.2 \\
\hline \multirow[t]{2}{*}{ Motivation } & $\begin{array}{l}\text { Promotions are based on seniority } \\
(\mathrm{p}<0.001)^{*}\end{array}$ & 25.7 & 11.3 \\
\hline & $\begin{array}{l}\text { Workers careers are managed so as to } \\
\text { enable the exchange of experiences between } \\
\text { workers of different ages }(\mathrm{p}<0.001)^{*}\end{array}$ & 56.9 & 69.5 \\
\hline \multirow[t]{3}{*}{$\begin{array}{l}\text { Intergenerational } \\
\text { transfer of } \\
\text { knowledge }\end{array}$} & $\begin{array}{l}\text { Training methods take account of the } \\
\text { exchange of experiences; mentoring; } \\
\text { coaching }(\mathrm{p}<0.001)^{*}\end{array}$ & 32.7 & 47.7 \\
\hline & $\begin{array}{l}\text { Work is performed in age-diversified teams } \\
(p<0.001)^{*}\end{array}$ & 43.1 & 67.3 \\
\hline & Knowledge management $(\mathrm{p}=0.001)^{*}$ & 56.2 & 68.0 \\
\hline \multicolumn{2}{|c|}{ Age is irrelevant $-\mathrm{it}$ 's performance that matters $(\mathrm{p}=0.782)$} & 95.4 & 95.8 \\
\hline
\end{tabular}

* See Table 1

Source: author's own elaboration. 
and employment planning, the selection of forms of employment, and an age-oriented organisation of work time. This shows the weight that is attached to formal aspects of employment and the concentration on ergonomic and organisational issues. However, the two types of organisations were almost identical regarding their perception of age from the perspective of worker performance. They were almost unanimous in their opinion that they did not pay much attention to the worker's age and the only thing that mattered to them was their individual performance (circa 95\%). This finding may point to a tendency to make the answers "politically correct", particularly in the case of traditional organisations that use outdated allowances for years of service, as well as revealing the focus of knowledgebased organisations on financial results.

A very important age-management tool is the healthcare services offered by the employer. Health-related services can be found in 12.7 percent of traditional organisations, compared with 13 percent of those based on knowledge. Health-care benefits offered as a non-financial incentive does not differentiate between employers, however this option was more frequent among firms building their advantage on intangible resources. These employers stressed that "fitness equipment is available on-site to workers and their families", that they offered "first-aid training" and "subsidised beverage vending machines", as well as health-improving incentives and opportunities such as "additional leave", "bonuses for no sick-leave days", "bike and mountain excursions for workers", "financial support as needed", and "additional insurance". The range of benefits is, therefore, fairly broad, although they are quite far from being common. It seems that employers are starting to perceive the need to develop work-life balance programmes, and to encourage pro-health attitudes based on prevention, healthy eating, and recreation.

In recent years, a small number of companies have begun to provide training promoting age-friendly attitudes, responding to the expectation of building a socially-responsible and diverse organisation. The survey results show a special philosophy of the organisation. Training in diversity management, i.e. a notion wider than age management, was much more popular than other types of training - it was provided in almost 20 percent of traditional firms. Promotion of diversity differentiates the respondents clearly and statistically significantly, a surprising fact being that this type of training was provided by almost 20 percent of traditional firms and only 10 percent of knowledge-based organisations. Training in age management 
enjoyed little popularity; its importance was appreciated by only around 2 percent (!) of firms. Work-life balance was a subject of training in 12.6 percent of traditional firms, compared with 8.4 percent of knowledgebased organisations, i.e., statistically significantly more frequently. Firms that considered buildings, land, and their stock of machines and equipment to be their most important assets more frequently organised training in age management, with work-life balance being closely related to it, as well as in diversity management. The acquisition of knowledge and skills for creating corporate social responsibility was somewhat more interesting for firms utilising intangible assets (although the correlation is statistically insignificant).

While traditional and knowledge-based organisations obviously differ, they operate in the same market. In our studies, differences were found in their perception of older people and the instrumental dimension of age management architecture. With regard to the functional perspective, it can be observed that it does not significantly differentiate Polish companies on the level at which decisions regarding age management are made. The perception of mature employees and the assessment of cooperation with trade unions are different. In terms of assessing job prospects, traditional and knowledge-based organizations are quite convergent, in addition to the "itdepends-on-how-resourceful-the-worker-is" indication, which differentiates them significantly.

The functional and instrumental perspective was presented jointly due to limited possibilities of publication volume. Both spheres differentiate employers and it is difficult to observe unambiguous regularities. Only the function related to the transfer of knowledge between employees of different ages includes instruments, all of which significantly differentiate between traditional and knowledge-based companies.

It seems that the remaining differences will fade. Most likely the differences in the institutional and functional spheres will disappear, and the instrumental sphere of age management will still be differentiated. This will probably not make a difference in the use of one or another instrument, but in its characteristics related to the degree of formalism, scope of content, and the number of users. Traditional and knowledge-based organisations can also differentiate their accents in different spheres related to the personnel function. These issues require more careful and deeper exploration. 


\section{DISCUSSION AND CONCLUSION}

The environment puts pressure on organisations through the way its changes affect them, including ageing populations, globalisation, the development of a knowledge-based economy, and computerisation. The organisation "looks in the mirror" of the environment and analyses its strengths and weaknesses, which leads to the creation of an age management strategy. This strategy is conditioned by the business strategy of the company, its organisational structure and culture, and the philosophy of HRM. Practices that bring equal benefits to workers and employers can include:

- management of competencies, including knowledge (organisational skills are a management binder, enabling organisations to objectivise personnel policy tools);

- increasing motivation to work, commitment, well-being;

- work-life-balance programs, i.e. packages of instruments to reconcile the work and private life of employees (Warwas, 2017).

Looking at age management in a broader perspective, it can be said that organisations should pay more attention to differences in the age structure of workers (Gajdzik, 2016) and try to create value-added intergenerational units (Lubrańska, 2016). It is necessary to include age diversity in management (Wiktorowicz et al., 2016) and conduct a thorough analysis of employee value systems and expectations as the basis for shaping motivational systems (Sajkiewicz, 2016) and creating employee engagement (Jawor-Joniewicz, 2016).

From this perspective, ageing can be seen as an opportunity. One of the biggest benefits of this trend is the development of knowledge-sharing companies (Fornalczyk et al., 2015). Mature workers can become mentors or consultants who support younger co-workers. Meanwhile, research shows that companies do not fully utilise this potential in elderly workers (Fornalczyk et al., 2015 and Jedrych, 2015). The age of employees is one of the dimensions of diversity management, and it can have a positive impact on a company's performance and enable the effectiveness of human resources management (Kopeć, 2016; Rakowska, 2014; Borkowska and Jawor-Joniewicz, 2016).

Practices that favour employers to a greater extent than workers include: (1) age diversity and generation management; (2) the training and development of employees; (3) flexibility in the workplace; and (4) monitoring and the study of work outcomes. There are fewer age 
management practices which are more beneficial to the employee than the employer, but here one can include employee health programs, a variety of medical care packages, and the practice of employer branding (Warwas, 2017). In the near future, in the area of age management, those practices which bring equal benefits to workers and employers will most likely develop most dynamically. It is also important to note that age management is a holistic approach (Sołtys and Warwas, 2016, Kolodziejczyk-Olczak et al., 2015), not just a bundle of practices. Regardless of whether we are aiming to retain employment or recruit mature employees from the labour market, the reasons for employing older employees by organizations are an interesting direction for further research, just like looking at age management from the silver economy perspective.

In light of research, it can be concluded that age management will develop in Poland ever more dynamically. This is due in part to the current low level of its implementation, but above all, it will result from the increasing labour market pressures and growing awareness of the numerous benefits of age management. These benefits relate not only to current activities but also to the context of future key challenges, thus the activities projected and forecasted regarding the issue of ageing should increase.

While traditional and knowledge-based organisations obviously differ, they operate in the same market. In our studies, differences were found in their perception of older people and the instrumental dimension of age management architecture. It seems that the remaining differences will fade. Probably the differences in the institutional and functional spheres will disappear, and the instrumental sphere of age management will still be differentiated. This most likely will not be a difference in the use of one or another instrument, but in its characteristics related to the degree of formalism, the scope of content, and the number of users. Traditional and knowledge-based organisations can also differentiate their accents in different spheres related to the personnel function. These issues still require more thorough and deeper exploration.

\section{REFERENCES}

Aassve, A., Arpino, B., Goisis, A., Grandparenting and mothers' labour force participation: A comparative analysis using the generations and gender survey, "Demographic Research", 27(3), pp. 53-84, 2012. 
Borkowska, S., Jawor-Joniewicz, A. (eds.), Ksztaltowanie zaangażowania pracowników $w$ kontekście zarządzania różnorodnościa [Shaping employee engagement in the context of diversity management]. Instytut Pracy i Spraw Socjalnych, Warsaw 2016.

Bugajska, J., Pracownicy starsi - możliwości i uwarunkowania fizyczne [Older employees opportunities and physical conditions]. CIOP-PIB, Warsaw 2007.

Clas-Hågan, N., Savinainen, M., Tapio, K., Lumme-Sandt, K. (eds.), Age management during the life course, p. 12. The Finnish Work Environment Fund, Tampere 2011.

Delay, B., Méda, D., Changes in the relation to work, Brussels 2008, http://www.ftunamur.org (accessed March 2013).

Fornalczyk, A., Stompór-Świderska, J., Ślazyk-Sobol M., Age management within organisations - employees' perceptions of the phenomenon. Research report, "Journal of Intercultural Management", 7(3), 2015, pp. 39-51.

Gajdzik, B., Zarzadzanie różnorodnościa wieku $w$ miejscu pracy [Managing diversity in the workplace], "Zarządzanie Zasobami Ludzkimi”, No. 3-4, 2016.

Henkens, K., Remery, C., Schippers, J., Shortages in an ageing market: An analysis of employers' behaviour, "International Journal of Human Resource Management", 19(7), pp. 1314-1329, 2008.

Jawor-Joniewicz, A., Budowanie zaangażowania pracowników z uwzględnieniem zarządzania różnorodnościa [Creating employee involvement with regard to diversity management], "Zarządzanie Zasobami Ludzkimi”, No. 3-4, 2016.

Jędrych, E., Zarządzanie wiedza pracowników 65 plus w organizacji [Knowledge management of employees aged $65+$ in an organization], "Zeszyty Naukowe Uczelni Vistula w Warszawie", 46(1), pp. 12-27, 2016.

Kaleta, A., Witek-Crabb, A., Participation in the strategic management process and the expansiveness of the strategy, "Argumenta Oeconomica" 1(34), 2015.

Kohlbacher, F., Herstatt, C. (eds.), The Silver Market Phenomenon. Marketing and Innovation in the Aging Society, p. VII. Springer, Berlin-Heidelberg 2011.

Kołodziejczyk-Olczak, I., Metodologiczna charakterystyka badań [Methodological characterics of the study] [in:] Kryńska, E., Krzyszkowski, J., Urbaniak, B., Wiktorowicz J. (eds.), Diagnoza obecnej sytuacji kobiet $i$ mężczyzn 50+ na rynku pracy $w$ Polsce. Raport końcowy [Diagnosis of the current situation of women and men aged 50+ on the labour market in Poland. Final report], p. 41. University of Lodz, Lodz 2013.

Kołodziejczyk-Olczak, I., Zarządzanie pracownikami dojrzałymi. Wyzwania i problemy [Management of mature employees. Challenges and problems]. University of Lodz Publishing House, Lodz 2014.

Kołodziejczyk-Olczak, I., Sołtys, A., Rashidi, A., Scott, L., Is management of aging human resources worthwhile? Evaluation of an age management model, "Intercultural Management", Vol. 7, Issue 1, pp. 75-95, 2015.

Kopeć, J., Dylematy zarzadzania różnorodnościa pracownicza [Dilemmas of employee diversity management], "Prace Naukowe Uniwersytetu Ekonomicznego we Wrocławiu", 430, pp. 176-184, 2016.

Kunze, F., Boehm, S. A., Bruch, H., Age diversity, age discrimination climate and performance consequences - a cross organizational study, "Journal of Organizational Behavior", Vol. 32, Issue 2, pp. 264-290, 2011. 
Lepak, D. P., Snell, S. A., The human resource architecture: Toward a theory of human capital allocation and development, "The Academy of Management Review", 24(1), pp. 31-48, 1999.

Lepak, D. P., Snell, S. A., Examining the human resource architecture: The relationships among human capital, employment, and human resource configurations, "Journal of Management", 28(4), pp. 517-543, 2002.

Lubrańska, A., Zespoty zróżnicowane wiekowo $w$ organizacji [Age-diversified teams in the organization], "Zarządzanie Zasobami Ludzkimi”, No. 3-4, 2016.

Ludwiczyński, A. (ed.), Architektura zarządzania zasobami ludzkimi w przedsiębiorstwach Liderach Konkursu HRM [Human resource management architecture in firms, leaders of HRM competition], WSPIZ, Warsaw 2005.

Macnicol, J., Age Discrimination. An Historical and Contemporary Analysis. Cambridge University Press, Cambridge 2006.

Mazur, A., Skrzek-Lubasińska, M., Kołodziejczyk, I., Anuszewska, I., Ślusarczyk, A., Podlejska, K., Filipek, M., Szanse i bariery zatrudnienia osób $w$ wieku $45+w$ województwie pomorskim [Opportunities and barriers to employment of people aged $45+$ in the Pomeranian Voivodeship]. WUP, Gdańsk 2009.

Misztal, J. (ed.), Uwarunkowania organizacyjne i psychologiczne Intermentoringu. Dla utrzymania osób 50+ na rynku pracy [Organizational and psychological conditions of intermentoring. To keep people aged 50+ in the labour market]. Żory 2006.

Nadler, D. A., Gerstein, M. S., Shaw, R. B. (eds.), Organisational Architecture. Jossey-Bass Publishers, San Francisco 1992.

Naegele, G., Walker, A., A guide to good practice in age management, Office for Official Publications of the European Communities, Luxembourg 2006.

Perek-Białas, J., Turek, K., Strzałkowska, H., Kononowicz, M., Michałowska, J., DrozdGarbacewicz, M., Jagiełło, M, Pracuje - rozwijam kompetencje. Innowacyjny model wsparcia dla pracowników 50+ [I work - I develop competence. Innovative support model for employees aged 50+], PBS DGA, Sopot 2011.

Perek-Białas, J., Turek, K., Aktywizacja potencjatu osób starszych [Activating the potential of the older], Presentation of results of the ASPA project, 2010.

Rakowska, A., Różnorodność zasobów ludzkich - stan badań $i$ wyzwania [Diversity of human resources - state of research and challenges], "Prace Naukowe Uniwersytetu Ekonomicznego we Wrocławiu", 349, pp. 351-360, 2014.

Reinmoeller, P., Service Innovation: Towards Designing New Business Models for Aging Societies, [in:] Kohlbacher, F., Herstatt, C. (eds.), The Silver Market Phenomenon. Marketing and Innovation in the Aging Society, p. 15. Springer, Berlin-Heidelberg 2011.

Sajkiewicz, B., Oczekiwania pracowników w różnym wieku jako podstawa budowy systemów zaangażowania opartych na zasadach zarządzania różnorodnościa - badania IPiSS [Expectations of workers of all ages as a basis for building engagement systems based on the principles of diversity management - IPiSS research], "Zarządzanie Zasobami Ludzkimi", No. 3-4, 2016.

Sołtys, A., Warwas, I., Kompleksowe zarzadzanie dojrzałymi pracownikami w organizacji [Comprehensive management of mature employees in the organization], "Przedsiębiorczość i Zarządzanie", Vol. XVII, No. 2, Part III, 2016. 
Urbaniak, B., Kołodziejczyk-Olczak, I., Raport z badań prowadzonych metoda wywiadu telefonicznego z trenerami szkoleń dla kandydatów na jobcoachów [Research report conducted by telephone interview with instruction trainers for jobcoach candidates], Intermediate report of the project “Alliance for labour", Łódź 2008.

Urbaniak, B., Zatrudnienie i instytucje rynku pracy $w$ warunkach starzejacych się zasobów pracy - badania dla Polski [Employment and labour market institutions under conditions of aging labour resources - research for Poland]. University of Lodz Publishing House, Lodz 2011.

Vendramin, P., Generations at work: Areas of solidarity and tensions. Brussels 2008.

Walker, A., Combating age barriers in employment - A European research report. European Foundation, Dublin 1997.

Walker, A., The emergence of age management in Europe, "International Journal of Organisational Behaviour" 10 (1), pp. 685-697, 2005.

Walker, A., Zaidi, A., New evidence on active ageing in Europe, Intereconomics, Forum. 2016.

Wallin, M., Hussi, T., Best practices in age management - evaluation of organisation cases. Final report, Finnish Work Environment Fund, 29.4.2011.

Warwas, I., Postawy wobec aktywności zawodowej starszych pracowników - perspektywa pracodawców [Attitudes toward older workers economic activity - employers' perspective], "Edukacja Ekonomistów i Menedżerów” No. 1 (39), 2016.

Warwas, I., Zarzadzanie wiekiem w Polsce - stan i perspektywy rozwoju [Age management in Poland - the state and prospects of development], "Polityka Społeczna" No. 4, 2017.

Wiktorowicz, J., Pracownicy $w$ wieku $45+w$ opinii pracodawców - wyniki badania $w$ sektorze MSP $w$ województwie tódzkim [Employees aged 45+ in the opinion of employers - results of research in the SME sector in the Lodz Region], [in:] Wiktorowicz, J., Kołodziejczyk-Olczak, I. Wieczorek, I., Fachowcy 45+ [Professionals aged 45+], Wydawnictwo SWSPiZ, Lodz 2010.

Wiktorowicz, J., Warwas, I., Kuba, M., Staszewska, E., Woszczyk, P., Stankiewicz, A., Kliombka-Jarzyna, J., Pokolenia - co się zmienia? Kompendium zarzadzania multigeneracyjnego [Generations - what is changing? Compendium of multigenerational management]. Wolters Kluwer, Warsaw 2016.

Woszczyk, P. (red.), Zarządzanie pracownikami 50+. Teoria a praktyka [Managing employees aged 50+. Theory and practice]. HRP, Lodz 2011.

Zając, Cz., Zarzadzanie zasobami ludzkimi w grupach kapitałowych [Human resources management in capital groups]. PWE, Warsaw 2012.

Received: October 2017, revised: February 2019 